\title{
MANUFACTURING SCHEME IMPACT OF SEEDBED PREPARATION ON QUALITY OF WHEAT SEEDS
}

\author{
Anatoly Lebedev, Vladimir Kuzminov, Sergey Ridniy, Pavel Lebedev \\ Stavropol State Agrarian University, Russia \\ lebedev.1962@mail.ru, ilichvova87@yandex.ru,mfsgau@mail.ru, zoya_lebedeva@mail.ru
}

\begin{abstract}
The article considers the manufacturing scheme of postharvest and seedbed preparation, and the research in winter wheat seed damage is carried out. The profitability of agricultural production is directly dependent on crop yields, which in turn depends on the quality of seed. High quality seeds are the most effective and low-cost factor in obtaining high and stable yields of agricultural crops. The quality of seed is strongly influenced by complex functional technology system post-harvest handling of seeds. Poor seed quality entails large cost overruns of seed, reducing the crop yield and to reduce the result of agricultural production. The main causes of injury to the seeds, is the impact of machines: harvesting and post-harvest seed preparation and mechanisms for transport of seed. The aim of our study was to study the injury to the seed material of winter wheat in preparation for planting in training experimental farm of the Stavropol state agrarian University. The object of study is the variety of winter wheat seeds Yuka. Preparation of wheat seeds for sowing in the teaching and experimental farm of the Stavropol state agrarian University includes operation, cleaning, transportation, storage, loading and unloading, cleaning and etching. The definition of injury to seeds was carried out using a binocular magnifier with magnification of 10-20 times with pre-staining of seeds in acrylic black paint Technological scheme of preparation of seed of wheat for sowing, which is used in teaching and experimental farm of the Stavropol state agrarian University, is quite common among agricultural enterprises engaged in cultivation of wheat. But for all its positive aspects this technology greatly injure the seed.
\end{abstract}

Key words: damage, seeds, wheat, pre-sowing, postharvest, seed preparation.

\section{Introduction}

The profitability of agricultural production is directly dependent on the crop yield, and the grain seed quality greatly affects it. High-quality seeds are the most effective and low-cost factors to obtain heavy and stable yields of crops.

The complex functional system of manufacturing techniques of postharvest seed treatment has a strong influence on the quality of the obtained seeds. A poor quality of seeds leads to a significant decrease of farm manufacturing techniques, which also involves a great over-expenditure of seed grain and a small harvest $[1 ; 2]$. The external (contact with friction surfaces) and internal factors (morphological-anatomical and physical-mechanical properties of corn seeds) impact seed damage as a result of interaction with movable operating elements of farm machines [3; 4]. The principle reasons causing seed damage are the influence of machines: harvesting machines, machines for postharvest seed preparation and machines for seed grain transportation.

\section{Materials and methods}

The purpose of our research was to study seed grain damage of winter wheat by one of the most widely-spread manufacturing schemes of postharvest and seedbed preparation, which is also used in the conditions of the instrumental-experimental farm of the Stavropol State Agrarian University.

The object of the study is winter wheat seeds of Yuka variety being soft type seeds, a shortstalked cereal (a height is up to 1 meter), resistant to bending (low lodging) and grain fall. The manufacturing scheme to prepare wheat seeds for sowing consists of such operations as harvesting, transportation, storage, loading-unloading work, cleaning and treatment. Seed harvesting is performed by combines (Across - 580 and New Holland - 6090), transportation is carried out by a dumper (ГА3), loading - by a front-end tractor loader $\mathrm{KУH}$, mechanical cleaning and sorting - by 3AB-40, seed treatment - by ПC-20 K4, seed loading into a planter - by a grain loader Stara.

The detection of seed damage [5] was performed by means of a binocular magnifier with magnification of 10-20 times with preliminarily coloured seeds by black acrylic paint in the following sequence.

1. To select an average sample of seeds by the corresponding technique according to the ГОСТ.

2. To count two probes in 100 pieces from the selected sample. To place the samples into a glass, to cover with dye and to shake. The solution concentration is $1 \%$. 
3. To pour out the solution in a minute, to lay out the seeds on the filter paper for removing any remaining water on them.

4. To count damaged seeds.

All damaged places (including invisible to the eye) on the endosperm and in the embryo area are intensely coloured and clearly come into sight on the grain surface due to the exposure to dye. Consequently, the seed tissue will be coloured in the damaged place.

The seeds are checked and put according to the damage groups, and then the overall percentage of the damaged seeds is summed up. If the selection of the pattern, sample and probe analysis is conducted properly, the difference between the two probes should not exceed $5 \%$. If the departures are greater, the third probe is taken.

At the same time, the different groups of damage have different effect on the biological properties of seeds. Many micro-traumas do not reduce the laboratory germination capacity, i.e. they do not give a complete picture of seed quality for different types of damage [6].

In the studies [7;8], it is noted that the field germination of many certified seeds is reduced up to 20-25\%, both the agro-technical factors and the seed grain quality affect it, the part of damaged seeds reducing germination is $60-70 \%$ among the total number of factors.

The field germination of seeds and the yield capacity of plants, being the most important, when obtained from these seeds also depend on damage type of corn grains [7]. The results of these researches are presented in Table 1.

Table 1

Laboratory, field germination and crop capacity of grain crops depending on the type of damaged seeds, percentagewise to the whole seeds

\begin{tabular}{|c|c|c|c|}
\hline $\begin{array}{c}\text { Indicator/ } \\
\text { Damage type }\end{array}$ & $\begin{array}{c}\text { Weak damage of } \\
\text { endosperm }\end{array}$ & Embryo & $\begin{array}{c}\text { Embryo and } \\
\text { endosperm }\end{array}$ \\
\hline $\begin{array}{c}\text { Laboratory } \\
\text { germination, \% }\end{array}$ & 100 & 92 & 82 \\
\hline $\begin{array}{c}\text { Field germination, } \\
\%\end{array}$ & 89 & 26 & 19 \\
\hline $\begin{array}{c}\text { Crop capacity in \% } \\
\text { to the whole seeds }\end{array}$ & 88 & 5 & 3 \\
\hline
\end{tabular}

In connection with the above-stated, the seeds were divided into 3 groups depending on the damage types:

A - fit; $\mathrm{B}$ - at the risk zone; $\mathrm{C}$ - not fit.

These groups are divided, in turn, into the following subgroups:

A1 - safe; A2 - slightly damaged;

B1 - destroyed seed coat; B2 - cracks / splits; B3 - damaged embryo;

$\mathrm{C} 1$ - knocked-out / destroyed embryo; C2 - grain is completely destroyed.

To calculate the total percentage of damage the $\mathrm{B}$ and $\mathrm{C}$ groups of seeds are summarized.

The samples to determine damage of wheat seeds were taken from the following places: 1) from the storehouse (after storage): up to this moment, the seeds were subjected by harvesting machines, transportation and storage during 3 months; 2 ) from the loading hopper $3 \mathrm{AB}$ : the seeds were delivered by a dumper from the storage place to $3 \mathrm{AB}$, and loading was done by a front-end tractor loader $\mathrm{K} \mathrm{YH}$; 3 ) from the hopper of clean seed $3 \mathrm{AB}$; 4) after treatment: the seeds were transported to the seed treater by the dumper, seed treatment was performed by $\Pi \mathrm{C}-20 \mathrm{~K} 4$; 5) from the planter: seed loading into a planter was performed by the grain loader Stara.

\section{Result and discussion}

The results of the research on the seed damage of wheat variety Yuka when prepared for sowing are presented in Table 1 and in Figure 2. 
As it is evident from Table 1 and Figure 2, the total seed damage as a result of seedbed preparation was $60.5 \%$, the obtained results are adequately coincided with the results of other researchers $[2 ; 7 ; 8]$; thus, the total seed damage is estimated in the range of $45-80 \%$ as a result of seedbed preparation. It is also necessary to point out that $4.5 \%$ of the seeds are not suitable for planting because an embryo is knocked out and a seed is completely destroyed.

The principle damage of wheat seeds when prepared for sowing is observed after harvesting (total damage is $37 \%$ ), and after mechanical cleaning and sorting, i.e. after preparation by $3 \mathrm{AB}$ (total damage is $63 \%$ ). One can also see that a combine does the greatest harm, practically for all damage groups, whereas $3 \mathrm{AB}$ increases dramatically the damage percentage on the subgroup B1. Loading, transportation work and treatment increase the damage percentage on the subgroup B2, B3, C1 and C2. The predominating type of seed damage is battered seedcoat (the subgroup B1) $-42 \%$ or $69 \%$ from the total number of the damaged seeds.

Table 2

Wheat seed damage (\%) when prepared for sowing

\begin{tabular}{|c|c|c|c|c|c|c|c|}
\hline \multirow{2}{*}{ Damage group / Place of sample intake } & \multicolumn{2}{|c|}{$\mathbf{A}$} & \multicolumn{3}{|c|}{$\mathbf{B}$} & \multicolumn{2}{|c|}{$\mathbf{C}$} \\
\hline & A1 & $\mathbf{A 2}$ & B1 & B2 & B3 & C1 & $\mathbf{C 2}$ \\
\hline 1. Storehouse (storage) & 43.5 & 17 & 16.5 & 10 & 10.5 & 1.5 & 1 \\
\hline Total: & \multicolumn{2}{|c|}{60.5} & \multicolumn{3}{|c|}{37} & \multicolumn{2}{|c|}{2.5} \\
\hline 2. From loading hopper 3AB & 42.5 & 11 & 27.5 & 3.5 & 7 & 4 & 4.5 \\
\hline Total: & \multicolumn{2}{|c|}{53.5} & \multicolumn{3}{|c|}{38} & \multicolumn{2}{|c|}{8.5} \\
\hline 3. After preparation $3 \mathrm{AB}$ & 35.5 & 6.5 & 48.5 & 1.5 & 7 & 0.5 & 0.5 \\
\hline Total: & \multicolumn{2}{|c|}{$\frac{1}{42}$} & \multicolumn{3}{|c|}{57} & \multicolumn{2}{|c|}{1} \\
\hline 4. After treatment & 34 & 7 & 50.5 & 1.5 & 4.5 & 0.5 & 2 \\
\hline Total: & \multicolumn{2}{|c|}{41} & \multicolumn{3}{|c|}{56.5} & \multicolumn{2}{|c|}{2.5} \\
\hline 5. After loading seeds into planter & 32 & 7.5 & 42 & 4 & 10 & 2.5 & 2 \\
\hline Total: & \multicolumn{2}{|c|}{39.5} & \multicolumn{3}{|c|}{56} & \multicolumn{2}{|c|}{4.5} \\
\hline
\end{tabular}

Great damage is caused by loading work and auger conveyors, with which a combine, $3 \mathrm{AB}$, a treater, a grain loader into a planter are equipped.

Moreover, the obtained researches showed that different subgroups of seed damage took place in different places.

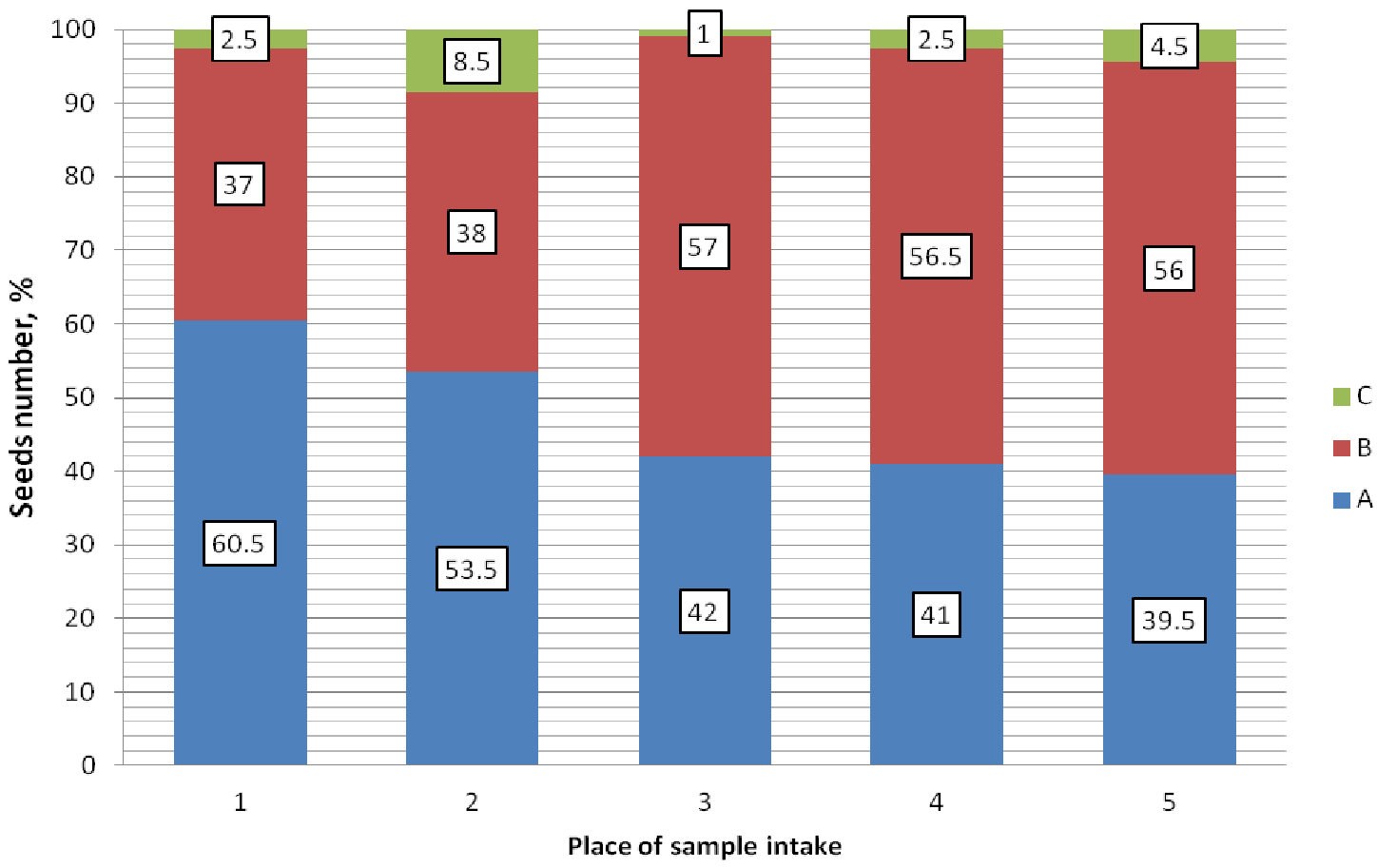

Fig. 2. Distribution of the type of traumas of wheat seeds in preparation for sowing 


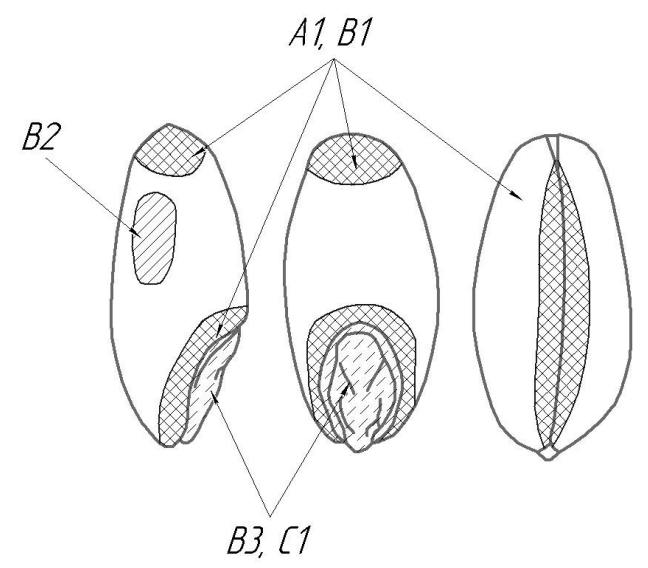

Fig. 3. Distribution according to the damage of wheat seeds
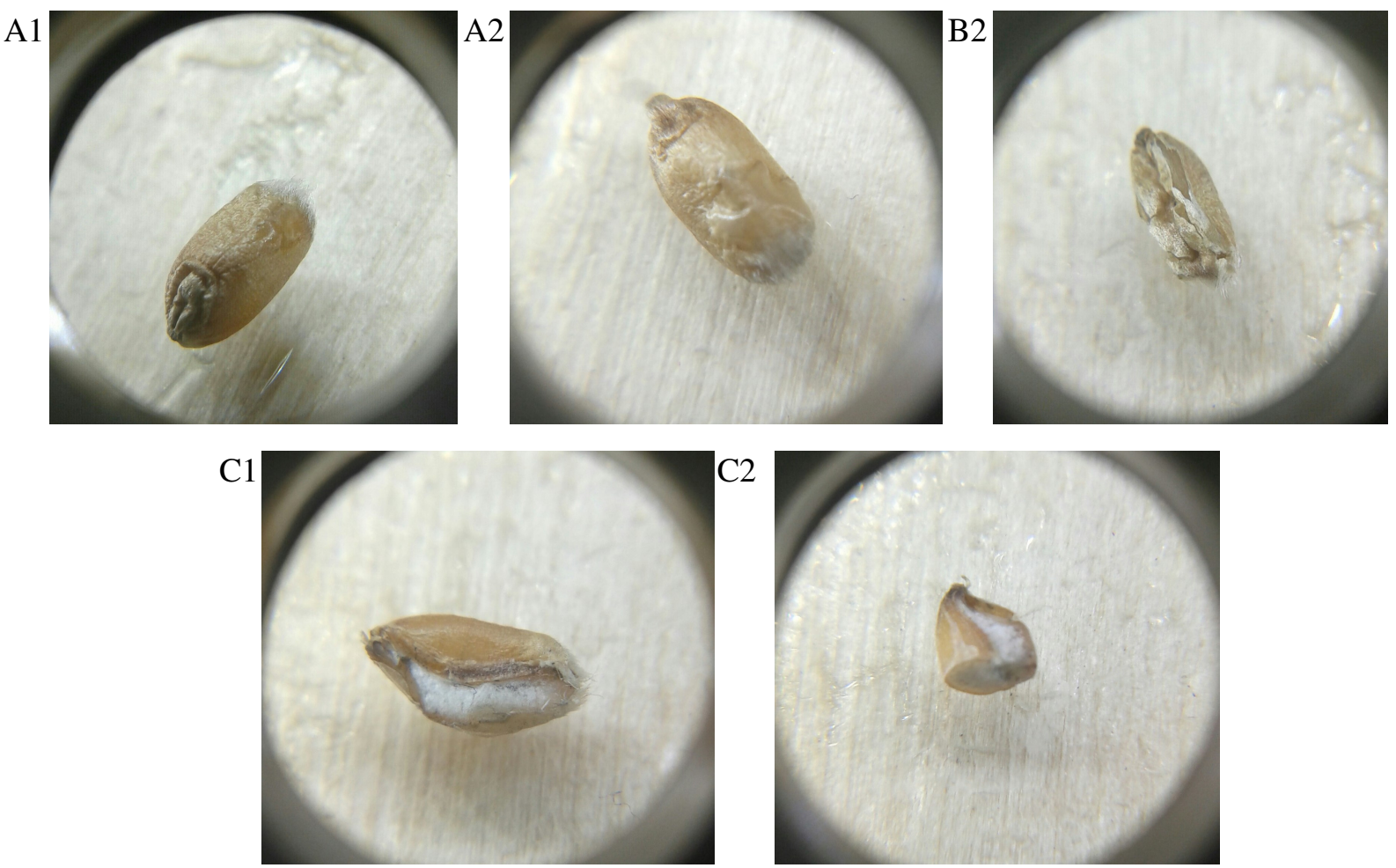

Fig. 4. Photographs of seeds of different types of damage

The subgroups A1 and B1 of damage (slightly damaged, shabby or battered seedcoat) are mainly found on a brush, around an embryo and a seedcoat near the grooves. The subgroup B2 has damage (cracks, splits) on the side. The damages (an embryo is damaged, knocked out, destroyed) are found in the embryo place of the wheat seed in the subgroup B3 and C1.

\section{Conclusions}

The manufacturing scheme in order to prepare grain seeds of wheat for sowing, which is used on the instrumental-experimental farm at the Stavropol State Agrarian University, is wide-spread among farm enterprises engaged in wheat cultivation. Regardless having positive aspects, this manufacturing technique substantially damages grain seeds. The following suggestions may be recommended for the reduction of wheat seed damage:

1. Application of soft litters for loading-unloading work to eliminate wheat seed knocks against a hard surface. 
2. Timely repair and maintenance of machines, which are used in the manufacturing techniques of wheat seed preparation for sowing.

\section{References}

1. Шафоростов В.Д., Тюрин А.А., Перетягин Е.А. Основные направления совершенствования технологии подготовки семенного материала высших репродукций подсолнечника. Масличные культуры Научно-технический бюллетень Всероссийского научноисследовательского института масличных культур. 2005. вып. 2 (133). с. 56 - 62. (Shaforstov V.D., Tyurin A.A., Peretyagin E.A. The Main Direction of Improving the Technology to Prepare Seed Grain of the Highest Reproduction of Sunflower. Oil-bearing crops. The scientific and technical bulletin of the All-Russian research institute of oil-bearing crops, Vol. 2 (133), pp. 5662, 2005). (In Russian).

2. Пехальский И.А., Кряжков В.М., Артюшин А.А. О количественной и качественной оценке травмирования семян машинами. Научный журнал КубГАУ, №119(05), 2016. с. 1-10. (Pechalski I. A., Kryazhkov V.M., Artushin A.A. On Quantitative and Qualitative Assessment of Seed Damage by Machines. The science journal of the Kuban State Agrarian University, №119 (05), pp 1-10, 2016). (In Russian).

3. Rademache F.J.C. On seed damage in Grain Augers. 3; agric. Engng Res. (1981) 26, pp. 87-96. (In Danish).

4. Кузнецов В.В., Манойлина С.3. Влияние внешних и внутренних факторов на процесс травмирования зерна. Вестник воронежского государственного аграрного университета. 2009. №2. c. 39-45. (Kuznetsov V.V., Manoilina C.Z. The Impact of the External and Internal Factors on Seed Damage. The Herald of the Voronezh State Agrarian University, № 2, pp 39-45, 2009). (In Russian).

5. Классификация травм семян и методы их определения. 2016: (The Classification of Seed Damage and Methods of their Determination. 2016: [online][28.01.2017]. Available at: http://www.agrodialog.com.ua/klassifikaciya-travm-semyan-i-metod-ix-opredeleniya.html (In Russian).

6. Скворцова Ю.Г., Ионова Е.В., Травмирование и посевные качества семян озимой мягкой пшеницы. Зернобобовые и крупяные культуры. №4(12). 2014. с. 104-107. (Skvortsova Y.G., Ivanova E.V. Damage and Sowing Qualities of Seeds of Soft Winter Wheat. Legume and Grain Crops. № 4 (12), pp104-107.2014). (In Russian).

7. Фадеев Л.В. Щадящая технология подготовки семян - путь повышения урожайности. 2011: (Fadeev L.V. Sparing technology of seed preparation - a way to increase crop capacity. 2011: [online][28.01.2017]. Available at: http://agro.imperja.com/index.pphp?id=1298305844. (In Russian).

8. Раенко Е.Ю., Блазнов А.Н. Влияние послеуборочной обработки на состояние семян. Научное сообщество студентов XXI столетия. Естественные науки: сб. ст. по мат. VI междунар. студ. науч.-практ. конф. № 6.(Ravenko E.U., Blaznov A.N. The Impact of the Seedbed Preparation on the Seed Condition. The scientific student community of the XXI century. Natural science: collected papers on mat. of the VI intern. stud. scientific.-pract. conf. № 6 : [online][20.03.2017]. Available at: sibac.info/archive/nature/StudNatur22.11.2012.pdf (In Russian). 